\title{
STUDY OF SHAPE OF INTERMEDIATE SILL ON THE DESIGN OF STILLING BASIN MODEL
}

\author{
H. L. Tiwari ${ }^{1}$, A vinash Panwar $^{2}$, Bharat Gehlot ${ }^{3}$, Jalam Singh ${ }^{4}$ \\ ${ }^{1}$ Department of Civil Engineering, Maulana Azad National Institute of Technology, Bhopal, Madhya Pradesh, India \\ ${ }^{2}$ Department of Civil Engineering, Maulana Azad National Institute of Technology, Bhopal, Madhya Pradesh, India \\ ${ }^{3}$ Department of Civil Engineering, Maulana Azad National Institute of Technology, Bhopal, Madhya Pradesh, India \\ ${ }^{4}$ Department of Civil Engineering, Maulana Azad National Institute of Technology, Bhopal, Madhya Pradesh, India
}

\begin{abstract}
The stilling basins are used to dissipate the energy of flowing water and protect the downstream structures like spillways, canals, etc. from the scouring. The aim of the present experimental investigation is to design the new stilling basin models for non circular pipe outlet using intermediate sill of different shapes having height equal to the diameter of pipe outlet. The experimental study was carried out for three Froude numbers namely 3.85, 2.85 and 1.85 for pipe outlet. Scour index (SI) has been used to evaluate the performance of stilling basin models with different shapes of intermediate sill, tested using same sand base material and test run time. The scour pattern was measured for each test run and flow pattern was also observed. After twelve tests runs, it was found that scour process were reduced for a shaped of intermediate sill having height equal to the diameter of pipe outlet at a particular location of intermediate sill combined with end sill of particular size and shape along with impact wall. Performance of this model having square shaped intermediate sill was found to be much better than USBR VI impact basin model for similar flow conditions.
\end{abstract}

Keywords: Model, Performance, pipe outlet, stilling basin, Scour index.

$* * *$

\section{INTRODUCTION}

Stilling basins with appurtenances like impact wall, intermediate sill, end sill, etc. can be used effectively in dissipating the excessive energy downstream of hydraulic structure like over flow spillway, sluices, pipe outlets, etc. The effect of sill on the flow depends upon the configuration of the sill, its shape and the flow regime [1]. Various types of recommended stilling basin models for pipe outlets are by Bradely and Peterka [2], Fiala and Maurice [3], Keim [4], Vollmer and Khader [5], Verma and Goel [6 \&7], Goel [8], Tiwari et al. [9,10, \&11], Tiwari and Gahlot [12] and Tiwari [13 \&14]. Appurtenances play an important role in the minimization of energy of flowing water in the stilling basin. A stilling basin for a pipe outlet consists of different appurtenances like impact wall, intermediate sill and an end sill, etc.

The sill height, configuration and position have great impact on the formation and control of hydraulic jump and ultimately leading to the dissipation of energy of flowing water. The present research paper concentrates on the improvement of the performance of stilling basin model by using different shape of intermediate sill of same height equivalent of diameter of pipe outlet along with end sill and impact wall. Performance of stilling basin models is compared with Scour index (SI). Lower value of SI indicates better performance of the model.

\section{MATERIALS AND METHODS}

\subsection{Experimental Arrangement}

The experiments were conducted in a recirculating laboratory flume in hydraulics lab. of MANIT Bhopal. The width of flume was reduced to $58.8 \mathrm{~cm}$ by constructing a brick wall along the length for keeping ratio of width of basin to equivalent diameter of rectangular outlet equal to 6.3 as per design of Gardes et al. [15]. The exit of pipe was kept above stilling basin by one equivalent diameter $(1 \mathrm{~d}=9.3 \mathrm{~cm})$. To observe the scour after the end sill of stilling basin an erodible bed was made of coarse sand passing through IS sieve opening $2.36 \mathrm{~mm}$. and retained on IS sieve opening $1.18 \mathrm{~mm}$. The maximum depth of scour $(\mathrm{dm})$ and its distance from end sill (ds) was measured for each test after one hour run time. The depth of flow over the erodible bed was maintained equal to the normal depth of flow. The discharge was measured by a venturimeter installed in the delivery pipe. After one hour the test run, the value of maximum depth of scour (dm) and its location from the end sill (ds) were noted. USBR VI model was tested with impact wall and end sill and then again models were tested with three different intermediate sills. All tested models with appurtenances are shown in Figures 1to 2. All the testing was performed for three Froude numbers namely, 3.85, 2.85 and 1.85 . Further scouring pattern was observed by using intermediate sill of same height with different shapes, kept at the distance of $4 \mathrm{~d}$ from the exit of the pipe, thus total 12 test 
runs were performed to design the stilling basin model using intermediate sill. Scheme of Experimentation is shown in

Table 1.

Table 1 Scheme of Experimentation

\begin{tabular}{|c|c|c|c|c|c|c|c|c|}
\hline \multicolumn{9}{|c|}{$\begin{array}{l}\text { Design of Models with different shape of Intermediate Sill along with Triangular End Sill }(1 \mathrm{~V}: 1 \mathrm{H}) \\
\text { of height } 1 \mathrm{~d} \text { for Basin Length } 8.4 \mathrm{~d}\end{array}$} \\
\hline \multirow[b]{2}{*}{ S.N. } & \multirow[b]{2}{*}{$\begin{array}{l}\text { Model } \\
\text { Name }\end{array}$} & \multicolumn{3}{|c|}{ Impact Wall with hood } & \multicolumn{4}{|c|}{ Intermediate sill } \\
\hline & & Size & $\begin{array}{l}\text { Bottom gap } \\
\text { with basin } \\
\text { floor }\end{array}$ & $\begin{array}{l}\text { Location } \\
\text { from } \\
\text { outlet } \\
\text { exit }\end{array}$ & Shape & Height & Width & $\begin{array}{l}\text { Location } \\
\text { from } \\
\text { outlet exit }\end{array}$ \\
\hline 1 & MSM-1 & $1 \mathrm{~d} \times 2.2 \mathrm{~d}$ & $1 d$ & $3 d$ & - & - & - & - \\
\hline 2 & MSM-2 & $1 \mathrm{~d} \times 2.2 \mathrm{~d}$ & $1 d$ & $3 d$ & $\begin{array}{l}\text { Triangular } \\
\text { with vertical } \\
\text { face D/S }\end{array}$ & $1 d$ & $1 d$ & $4 d$ \\
\hline 3 & MSM-3 & $1 \mathrm{~d} \times 2.2 \mathrm{~d}$ & $1 d$ & $3 d$ & Rectangular & $1 d$ & $0.2 \mathrm{~d}$ & $4 d$ \\
\hline 4 & MSM-4 & $1 \mathrm{~d} \times 2.2 \mathrm{~d}$ & $1 d$ & $3 d$ & Square & $1 \mathrm{~d}$ & $1 \mathrm{~d}$ & $4 d$ \\
\hline
\end{tabular}

\section{CRITERIA FOR PERFORMANCE}

\section{EVALUATION OF STILLING BASIN}

The performance of a stilling basin model was tested for different Froude number (Fr) which is a function of channel velocity $(v)$, the maximum depth of scour $\left(\mathrm{d}_{\mathrm{m}}\right)$ and its location from end sill $\left(\mathrm{d}_{\mathrm{s}}\right)$. A stilling basin model that produces smaller depth of scour at a longer distance is considered to have a better performance as compared to another stilling basin which results in a larger depth of scour at a shorter distance when tested under similar flow condition, Verma \& Goel (2003) as illustrated in Figure3. A non dimensional scour index $\left(\mathrm{SI}=2 \mathrm{~d}_{\mathrm{m}} / \mathrm{d}_{\mathrm{s}}\right.$ ), as proposed by Goel \& Verma (2001), has been considered for comparison of performance of stilling basin models. A smaller value of scour index shows better performance of stilling basin models. The value of scour indices for various runs on each model for different Froude numbers are given in Table No. 2.

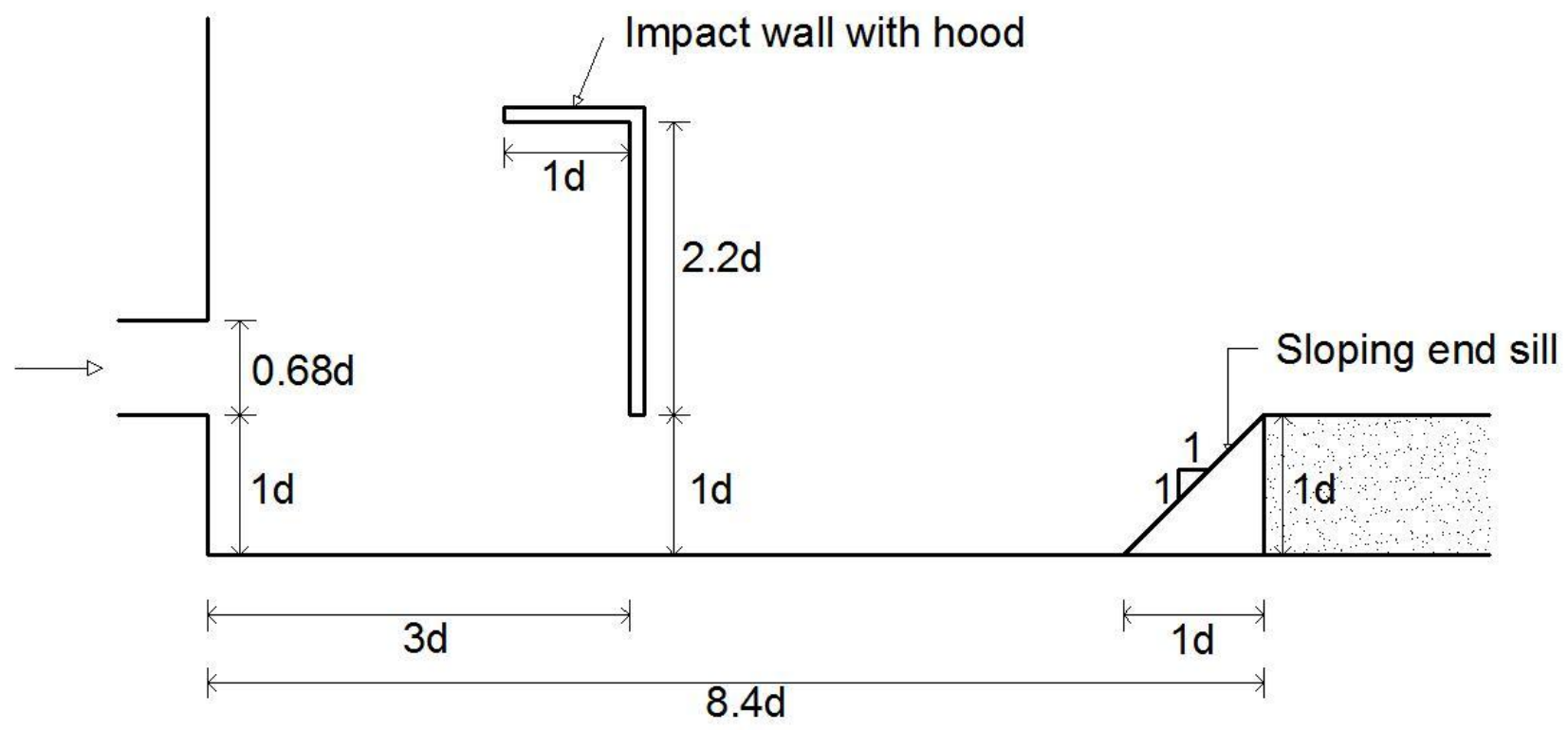

MSM-1(USBR VI Impact basin model) 


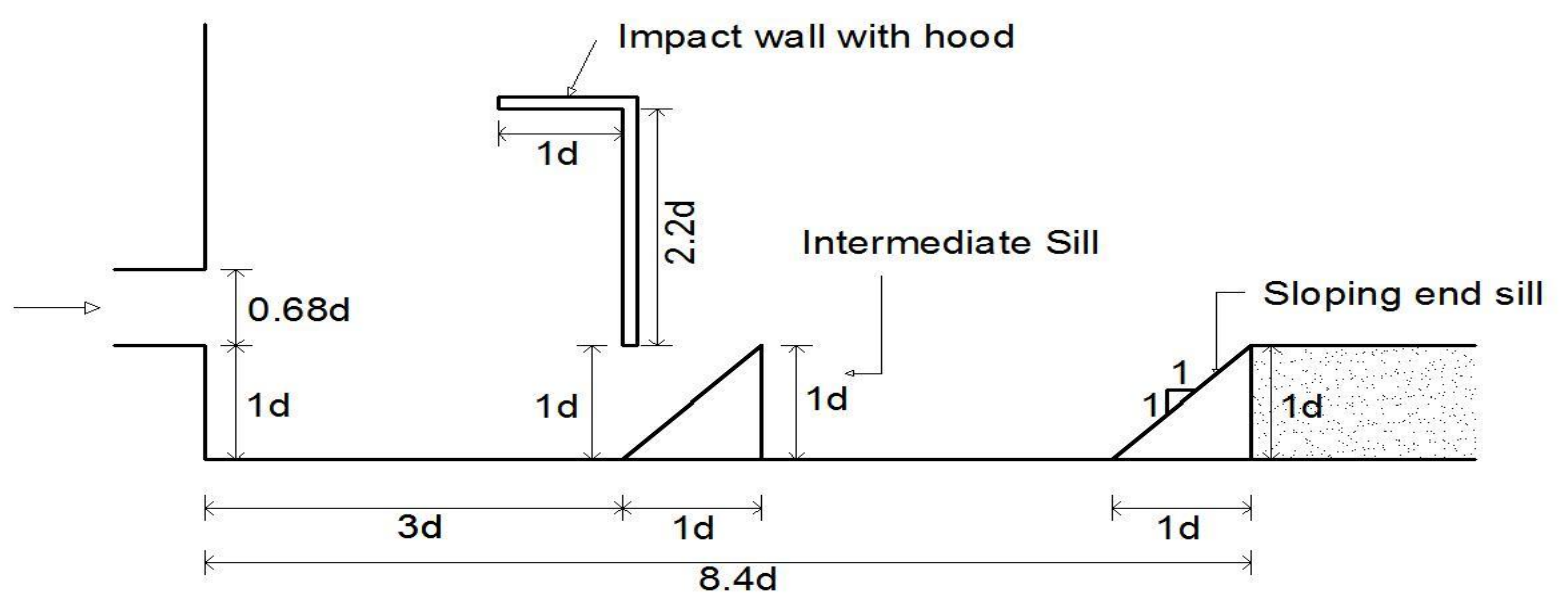

MSM-2

Fig 1 Models, MSM-1 and MSM-2 with triangular intermediate sill along with impact wall and end sill

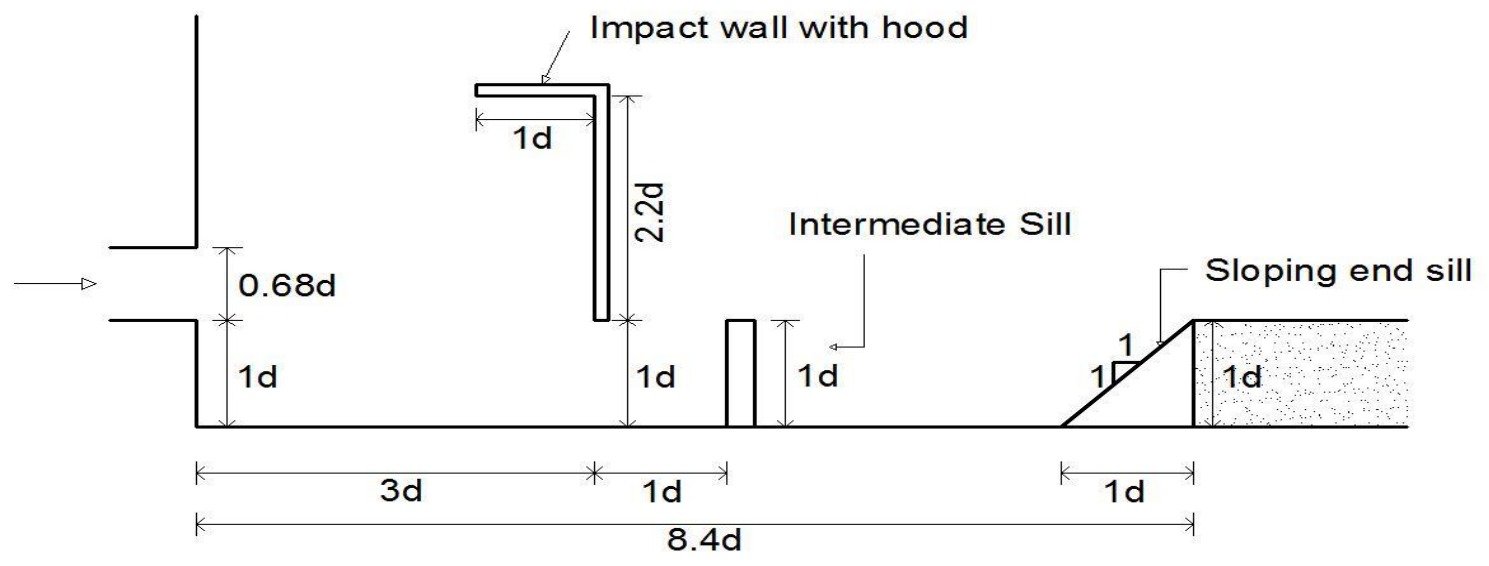

MSM-3

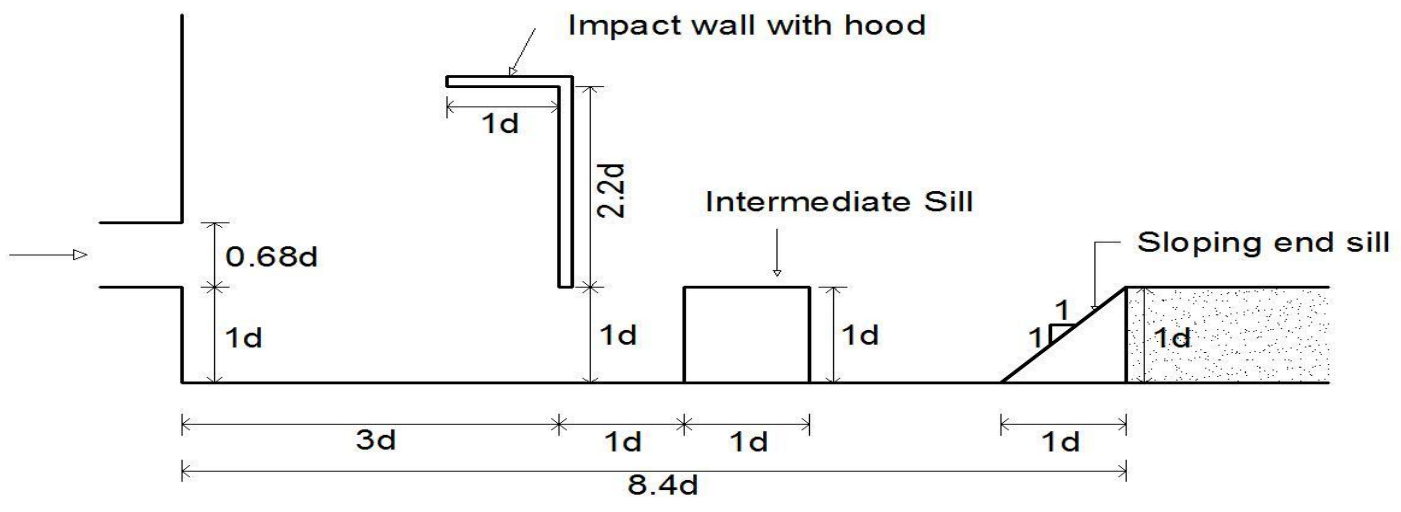

MSM-4

Fig 2 Models MSM-3 \& MSM-4 with rectangular and square intermediate sill along with impact wall and end sill 


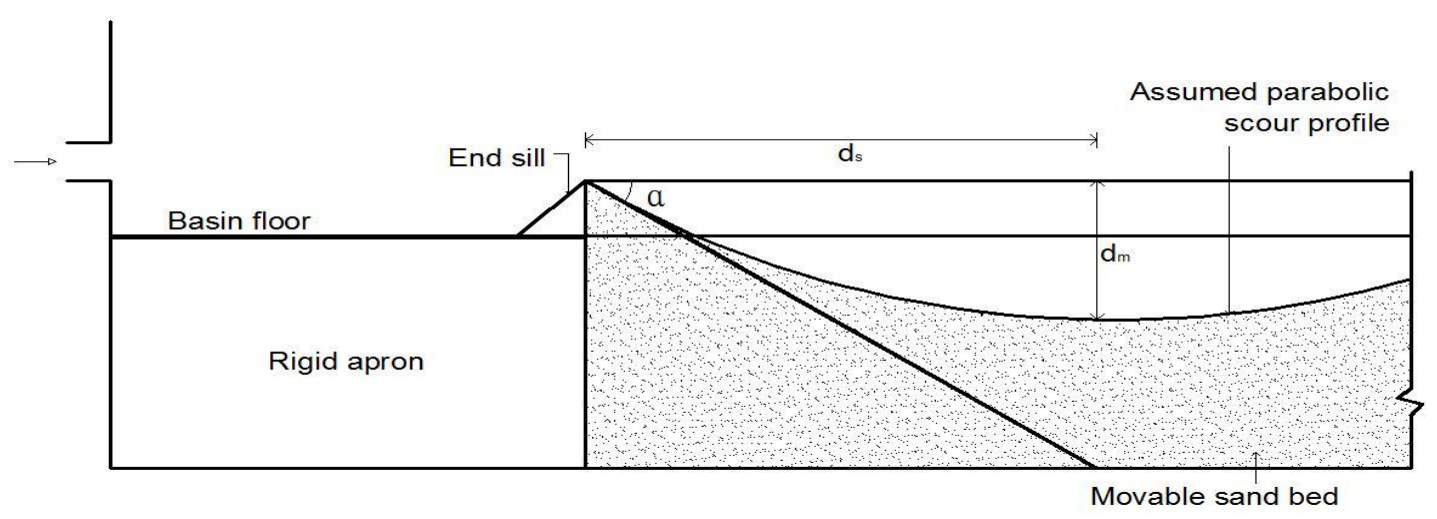

Fig- 3 Assumed Scour Pattern

\section{RESULTS AND DISCUSSIONS}

To study the effect of geometry of intermediate sill on the performance of stilling basin models for pipe outlet, five models, were tested for three Froude numbers, namely 1.85, 2.85 and 3.85. The data pertaining to depth of scour and its location from end sill were collected for each model and reported in table 2 to evaluate their performance by using performance index. First of all USBR VI model (MSM-1) was tested and values of SI was computed as $0.609,0.706 \& 0.893$ for $\mathrm{Fr}=1.85,2.85$ and 3.85 respectively.
In continuation of the investigation of the geometry of intermediate sill, the performance of the basin models were tested with intermediate sill of sloping, rectangular and square with same height along with impact wall located at $3 \mathrm{~d}$ and sloping end sill fixed at 8.4d. In models MSM-2 vertical face of the sloping end sill was downstream, with 1d. Further models MSM-3 and MSM-4 were tested with rectangular and square intermediate sill with same height of $1 \mathrm{~d}$. It was found that model with square intermediate sill produces higher values of SI $(0.322,0.352 \& 0.372)$ as compared to other tested models as shown in Table2.

Table -2 Scour index for different models tested with ES, IW and IS

\begin{tabular}{|l|l|l|l|l|l|l|l|l|l|l|}
\hline S. & Model & \multicolumn{4}{l|}{ Fr $=1.85$} & \multicolumn{2}{l|}{ Fr $=2.85$} & \multicolumn{2}{l|}{ Fr $=3.85$} \\
No. & name & dm & ds & SI & dm & ds & SI & dm & ds & SI \\
\hline 1 & MSM-1 & 3.2 & 10.5 & 0.609 & 4.4 & 12.5 & 0.706 & 4.6 & 15.5 & 0.893 \\
\hline 2 & MSM-2 & 1.4 & 7.9 & 0.354 & 2.4 & 11.8 & 0.406 & 3.1 & 13.4 & 0.462 \\
\hline 3 & MSM-3 & 0.8 & 5.1 & 0.313 & 1.5 & 8.2 & 0.366 & 2.2 & 11.1 & 0.396 \\
\hline 4 & MSM-4 & 0.3 & 3.1 & 0.322 & 0.6 & 3.4 & 0.352 & 0.8 & 4.3 & 0.372 \\
\hline
\end{tabular}

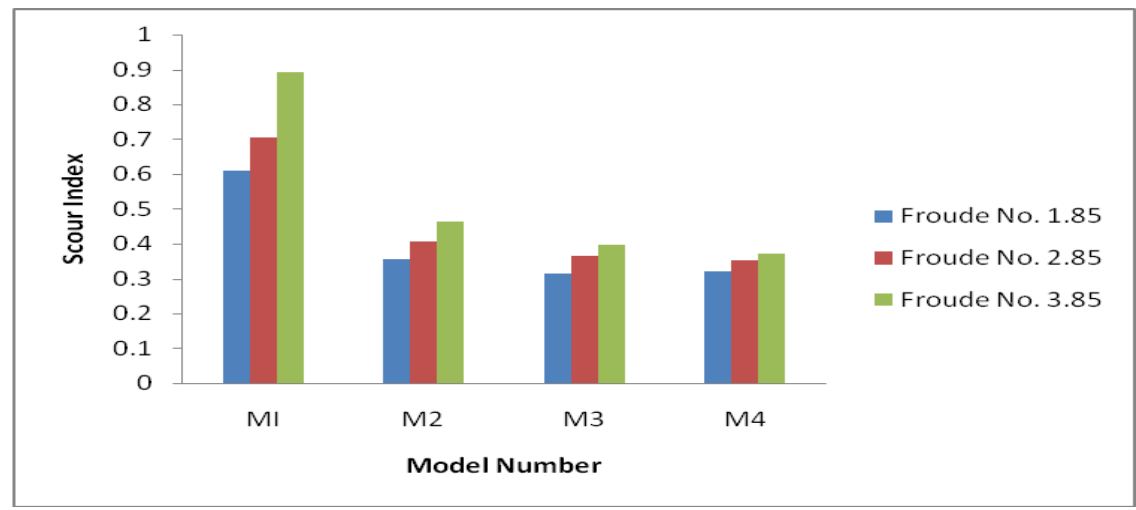

Fig-4 Comparision of performance for different models 
It is also shown in bar chart in Fig.4. After analysis, it was found that by changing the shape of intermediate sill, there is improvement in the performance of the basin. It is so because of impact action, a reduction of energy is more, thereby improvement of the basin performance. Intermediate sill of square shape promotes the dissipation of energy in the basin by lifting high velocity filaments from the bed. No doubt performance of the stilling basin models improves with the inclusion of intermediate sill, which also confirms the findings of Negm [1]. Similar finding was also reported by Tiwari \& Tiwari [16].

Table 2 and Fig. 4 clearly indicates that for all tested Froude numbers values of scour indices are reduced in designed model M4 as compared to USBRV I model (M-1). Comparison of these models is given in Table 3. This comparison shows that there is improvement in performance from $47.2 \%$ to $58.3 \%$ in newly designed model over USBR VI model by simply inserting square shaped intermediate sill.

Table 3 Comparison of new designed model with USBR VI model

\begin{tabular}{|l|l|l|l|l|}
\hline Name of model & SI for Fr $=1.85$ & SI for Fr $=2.85$ & SI for Fr = 3.85 & Remark \\
\hline M-4 & 0.322 & 0.352 & 0.372 & Developed model \\
\hline M-1 & 0.609 & 0.706 & 0.893 & USBR VI model \\
\hline \multicolumn{4}{|l|}{ Improvement of performance for all Froude Numbers } \\
\hline $\begin{array}{l}\text { improvement in } \\
\text { performance of } \\
\text { designed model } \\
\text { over USBR VI } \\
\text { model }\end{array}$ & $50.1 \%$ & $58.3 \%$ & $\begin{array}{l}\text { Much improved } \\
\text { performance for all }\end{array}$ \\
\hline
\end{tabular}

\section{CONCLUSIONS}

An experimental investigation was conducted to study the effect of Shape of inter mediate sills along with impact wall and end sill. Three intermediate sills of different shape were tested. The scouring is significantly reduced there by reducing the scour index for square intermediate sill of height $d$ and base width $d$, placed at the distance of $4 d$ from the exit of pipe outlet. It is found that intermediate sill of square cross section used in model MSM-4, produces lower scour indices and thus performs better as compared to all other tested models for all Froude numbers tested. Based on the results of experimental studies on stilling basin models, it can be concluded that the shape of intermediate sill greatly affect the performance of a stilling basin. Efficient stilling basin model (MSM-4) has been evolved by experimentation as compared to USBR VI stilling basin model. Similar reporting was observed in [17].

\section{REFERENCES}

[1] Negm, A.M. (2004), Effect of sill arrangement on maximum scour depth DS of abruptly enlarged stilling basins. Proc. of Int. Conf. Hydraulics of Dams and River Hydraulics, 26-28 April, Tehran, Iran.

[2] Bradley, J.N., Peterka, A. J. (1957), Hydraulic Design of Stilling Basins, Journal of A.S.C.E. Hydraulic Engg, , 83(5), 1401-1406.

[3] Fiala, J. R. and Maurice, L. A. (1961), Manifold Stilling Basins, Journal of A.S.C.E., Hydraulic Div.. 87(4), pp.55-81.
[4] Keim, S. R. (1962), Contra Costa Energy Dissipator. Journal of A.S.C.E., Hydraulic Division, 3077, March, , pp. 109-122.

[5] Vollmer, E., Khader, M.H.A. (1971), Counter Current Energy Dissipator for Conduit Outlets, International J. of Water Power, 23(7), 260-263.

[6] Verma, D.V.S, Goel, A. (2000), Stilling Basins for Outlets Using Wedge Shaped Splitter Blocks, ASCE Journal of Irrigation and Drainage Engineering126 (3), 179-184,

[7] Verma, D.V.S. Goel, A.( 2003), Development of Efficient stilling basins for Pipe Outlets, ASCE Journal of Irrigation and Drainage Eng..129(3), 194-200.

[8] Goel, A. (2008), Design of Stilling Basin for Circular Pipe Outlet. Canadian Journal of Civil Engineering, 35 (12), pp. 1365-1374.

[9] Tiwari, H.L., Goel, A. and Gahlot, V.K. (2011), Experimental Study of Sill Controlled Stilling Basins for Pipe Outlet, International Journal of Civil Engg. Research, 2(2),pp. 107-117.

[10] Tiwari, H.L., Goel, A. and Gahlot, V.K. (2011), Experimental Study of effect of end sill on stilling basin performance, International Journal of Engg. Sci. and Technology, 3(4), pp.3134-3140.

[11] Tiwari, H.L, Gahlot, V.K. and Tiwari Seema, (2013), Reduction of Scour depth downstream of stilling basin, International Research Journal of Engineering Sciences. 2(7), pp.20-25.

[12] Tiwari, H.L.and Gahlot, V. K. (2012), Experiments on new Stilling basin for Pipe outlets, STM, AISECT University, 2(2), pp. 17-20. 
[13] Tiwari, H.L.( 2013), Design of Stilling Basin with Impact wall and End sill, International Research Journal of Resent Sciences, 2(3), pp.59-63.

[14] Tiwari, H.L. (2013), Analysis of Baffle wall gap in the Design of Stilling Basin Models , International Journal of Civil Engineering and Technology, 4( 4), pp.66-71.

[15] Garde, R .J., Saraf, P.D., Dahigaonkar, D.J. (1986), Evolution of Design of Energy Dissipator for Pipe Outlets, J. of Irrigation \& Power, 41(3), pp.145-154.

[16] Tiwari, H.L. and Tiwari Seema (2013), Design of Stilling Basin Models with Intermediate sill, Journal of Science, Technology and Management, 2(4), pp.66-71.

[17] Tiwari, H.L, Gahlot, V.K. and Sharma Abhay, (2014), Effect of intermediate sill on the perforformance of stilling basin models, International J. of Sc. Engg. \& Tech. 3 (6), pp.414-417. 